\title{
AGE-RELATED SEROPREVALENCE STUDY FOR ST. LOUIS ENCEPHALITIS IN A POPULATION FROM CORDOBA, ARGENTINA
}

\author{
Lorena Ivana SPINSANTI(1), Viviana Elizabeth RÉ(1), María Pilar DÍAZ(2) \& Marta Silvia CONTIGIANI(1)
}

\begin{abstract}
SUMMARY
A serological screening was performed in 615 individuals aged 0-87 years, living in the city of Cordoba, Argentina to study the relationship between antibody prevalence for the SLE virus and age.

A $13.98 \%$ prevalence of neutralizing antibodies was obtained and its relation to age was significantly high $(\mathrm{p}=0.045)$. The highest seroprevalence was noted on individuals over 60 years old $(>20 \%)$, whereas no subject under 10 was seropositive for this virus.

Our results confirm that the agent is endemic in this area and neurological pathology studies should be performed on those individuals aged 60 since they represent the most susceptible group to SLE virus.
\end{abstract}

KEYWORDS: Seroprevalence; St. Louis encephalitis; Age; Córdoba, Argentina

\section{INTRODUCTION}

St. Louis encephalitis (SLE) is a human mosquito-borne viral disease. The causative agent, SLE virus, is a member of the Flaviviridae family. It was first isolated in Missouri in 1933, and it has been responsible for more than 4,000 reported human cases of infection in the United States since $1955^{10}$. Several reports have shown that SLE virus is widely distributed in the Americas; it has been isolated from Canada to Argentina ${ }^{1}$. The results of several serological surveys suggest that SLE virus is able to infect man in Central and South America ${ }^{1,2,11}$, and seems to cause sporadic illness as the few isolations obtained from human blood in Argentina, Panama, and Trinidad came from patients with a mild febrile illness ${ }^{1}$. One case of fever and jaundice has been reported in Brazil, but cases of encephalitis caused by SLE virus have not been reported ${ }^{12}$.

Three clinical syndromes are described associated with the infection: encephalitis, aseptic meningitis, and febrile headache. The occurrence and severity of SLE in human beings is strongly dependent on age. It has been reported that during epidemics, incidence of disease in persons older than 60 years was generally 5-40 times greater than in those less than 10 years old and the case-fatality rate increased with age, from $2 \%$ in young adults to over $22 \%$ in the elderly ${ }^{10}$.

In Argentina the distribution of SLE virus is very wide, the serological evidence (in some cases up to 50\%) for transmission has been found practically wherever it has been sought. The virus is endemic in subtropical provinces, as well as in other regions located in the temperate area of Argentina. However, the SLE infection has been rarely associated to human illness in Argentina and South America ${ }^{13,14}$.

In the province of Buenos Aires in 1963, two clinical cases characterized by febrile syndromes, without signs of central nervous system infection were reported and diagnosed by virus isolation and serology ${ }^{7}$. Between 1966 and 1984 two viruses were isolated from unusual sources in the province of Córdoba: the strain Cba. An 9124 from the urine of a Calomys sp and the strain Cba. An 9275 from a brain-spleen pool of a juvenile Mus musculus ${ }^{13}$. Afterwards, 6 other strains of SLE were recovered from Culex sp mosquitoes in the province of Santa $\mathrm{Fe}^{8,9}$.

In molecular studies of genetic variability and its relationship to virulence TRENT et al. established 5 genotypes and showed that none of the Argentine strains had the epidemic North American genotype from the Central and Atlantic Coast States of USA, represented by the MSI-7 strain $^{15}$.

Until now no study was done in order to provide information about age-specific immunity rates or the prevalence of infection in rural vs. urban populations in Argentina. A high prevalence of immunity in the population over 60 years old, representing the age group most susceptible to clinical disease, could explain the absence of epidemics in the region ${ }^{13}$.

A serological screening was performed in 615 individuals age range 0 to 87 years, living in Cordoba, Argentina to evaluate the association

(1) Institute of Virology "Dr. J.M.Vanella”, Faculty of Medical Sciences, National University of Cordoba, Argentina.

(2) Statistics and Biometrics, Faculty of Agronomy, National University of Cordoba, Argentina.

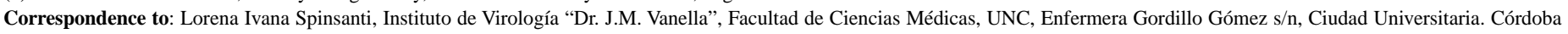
5016, Argentina. Tel: 54 - (351) 4334022; e-mail: contigia@ cmefcm.uncor.edu 
and functional relationship between the prevalence of SLE infections and the age of individuals.

\section{MATERIAL AND METHODS}

Area studied: This study was performed in the city of Cordoba which is the main inland province of Argentina (Fig. 1). This city has a sub-temperate climate (transition temperate) and it has all the characteristics corresponding to an urban system. The annual average rainfall is $727 \mathrm{~mm}$ and it had 1,179,067 habitants in 1991 .

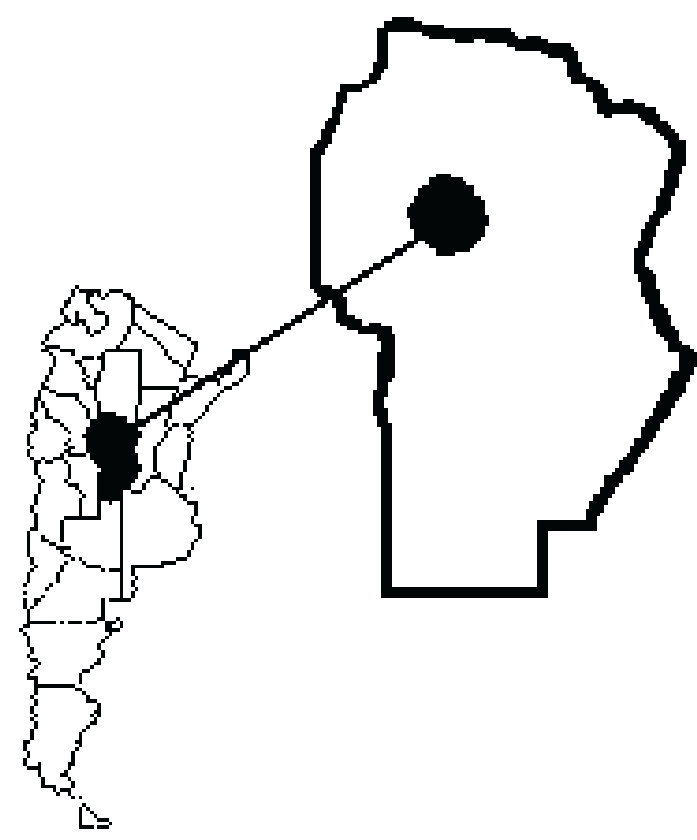

Fig. 1 - Insert shows the city of Cordoba in the Cordoba province, Argentina.

Human Serum: Between 1998 and 2000 period 615 serum samples were studied. They were taken from individuals belonging to the Blood Bank (aged between 16 and 55 year-old) Infantile Hospital and from the health care allocation for those people over 60 who had a check up at that moment. All the individuals coming from these places were considered representatives of the different neighborhoods of the city. The samples were preserved at $-20{ }^{\circ} \mathrm{C}$ until they were processed.
Serological test: Plaque reduction neutralization test was performed with an $80 \%$ plaque reduction endpoint ${ }^{3}$. The viral suspension was prepared using a mouse's brain infected by SLE 78V6507 strain to $10 \%$ (weight/volume) in Medium Essential Minimum (MEM) with Earle, Lglutamine salts, $10 \%$ of fetal bovine serum and antibiotic. It was centrifuged at 10,000 rpm during 30 minutes so as to decontaminate. In the screening was used a 1:5 dilution of each serum.

Statistical Analysis: Age distribution was studied and turned into a discrete variable with 16 intervals. The middle point of each class was taken to represent age covariate in the prevalence study. Generalized linear models, with logistic link, were fitted ${ }^{6}$ for the response variable: number of positive subjects, assuming linear and quadratic regression model for the linear predictor. The system GLIM (Generalized Interactive Linear Models $)^{5}$ was used to do it. Several checking techniques were implemented for the diagnostic analysis in order to obtain a suitable model for predictions.

\section{RESULTS}

Table 1 summarizes all the information related to the study showing the prevalence values obtained according to the age turned into discrete 7 intervals. It can be noted that the prevalence gradually increases from 10 years and that it is higher in adults over 60 .

Table 2 shows the deviance analysis results for the adjustments on the logistic models having $\eta=\alpha+\beta_{1}$ Age $+\beta_{2}$ Age $^{2}$ (quadratic linear regression) and the parameters estimated for the model as a systematic component.

Table 1

Prevalence of SLE neutralizing antibodies according to age in individuals from Cordoba, Argentina

\begin{tabular}{ccc}
\hline Age (years) & Positive/tested & Prevalence $(\%)$ \\
\hline $0-9$ & $0 / 91$ & 0 \\
$10-19$ & $3 / 51$ & 5.9 \\
$20-29$ & $14 / 148$ & 9.5 \\
$30-39$ & $11 / 76$ & 14.5 \\
$40-49$ & $9 / 63$ & 14.3 \\
$50-59$ & $6 / 26$ & 23.1 \\
$>60$ & $43 / 160$ & 26.9 \\
\hline TOTAL & $86 / 615$ & 13.98 \\
\hline
\end{tabular}

Table 2

Deviance analysis from logistic regression model, estimates and standard errors, p-value and fitted models

\begin{tabular}{lcccc}
\hline Parameter & Estimate & Standard error & p-value & Adjusted model \\
\hline$\alpha$ (intercept) & -4.2010 & 0.6144 & 0.0000 & \\
$\beta_{1}$ (linear coefficient) & 0.0839 & 0.0282 & 0.0000 & $\ln (\mathrm{p} / 1-\mathrm{p})^{(1)}=-4.2010+0.0839$ age -0.0055 age ${ }^{2}$ \\
$\beta_{2}$ (quadratic coefficient) & -0.00055 & 0.0022 & 0.0455 & \\
\hline
\end{tabular}

\footnotetext{
(1) $\mathrm{p}$ is the positive proportion (prevalence/100).
} 
The p-values to covariable incorporation showed that prevalence was strongly related to individuals age. The determining coefficient value for the adjusted model $\mathrm{R}^{2}=0.821$ show that approximately $80 \%$ of the prevalence can be explained by age relation.

Figure 2 shows the estimated prevalence for different ages.

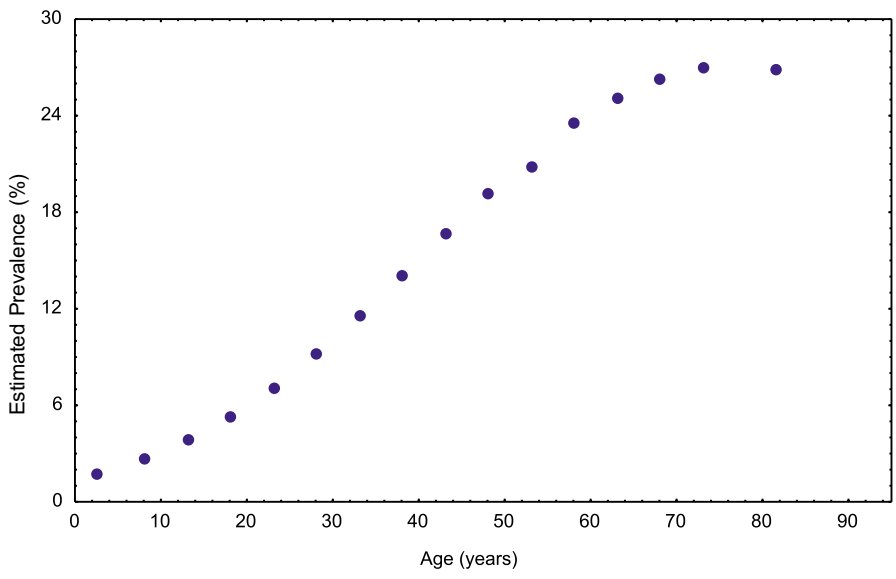

Fig. 2 - Estimated prevalence for different age values

\section{DISCUSSION}

In Cordoba the last records related to SLE virus circulation date from 1963-66 when EVANS et al. found 11\% of antibodies in men aged $20^{4}$. The results of our study showed a seroprevalence slightly higher $(13.98 \%)$ and a significant statistical relationship between the presence of neutralizing antibodies and the age of the subjects $(\mathrm{p}=0.045)$.

The prevalence estimated by the statistical model according to age (Fig. 2) showed that the seroprevalence would be more than $20 \%$ in adults over 60 . However, the absence of specific antibodies for the SLE in children under 10 (Table 1) (the statistical model predicts or estimates a low prevalence, Fig. 2) could be due that during the last decade the virus remained silent in the area studied. It would be interesting to extend this study among individuals under 10 from other areas to check if the same behavior is repeated.

Despite the relationship between SLE prevalence and age is statistically significative, the quantity of samples studied in the 50-60 years old group was lower than in the other age groups.

A higher number of samples would reinforce the significance of these results.

One explanation for the rarity of cases in humans in Argentina is the probable accumulation of immunity with age, thereby reducing the size of the susceptible elderly population. Furthermore, the cases of milder febrile syndromes and the Central Nervous System infections that could be associated to the SLE infection are not yet researched.

The highest antibody prevalence to the SLE virus found among individuals over 60 years old points out that the presence of neurological pathologies in these subjects should be investigated to better understand the etiological role of SLE virus in Argentina.

\section{RESUMO}

\section{Estudo da prevalência para vírus da encefalite St. Louis relacionado com a idade em uma população de Córdoba, Argentina}

Com a finalidade de estudar a relação entre prevalência de anticorpo para o vírus da encefalite St. Louis (ESL) e a idade, foram analisados 615 soros de indivíduos entre 0-87 anos de idade, morando na cidade de Córdoba, Argentina.

Detectou-se uma prevalência de anticorpos neutralizantes de 13,98\% e observou-se uma relação com a idade estatisticamente significante ( $\mathrm{p}$ $=0,045)$. A soroprevalência mais alta foi encontrada em indivíduos de mais de 60 anos (> 20\%), enquanto nenhum com menos de 10 anos foi soropositivo para este vírus.

Nossos resultados confirmam que o agente é endêmico nesta área. Por esse motivo os autores sugerem que deveríam se realizar estudos de patologias neurológicas nesses indivíduos de 60 anos de idade dado que eles representam o grupo mais suscetível ao vírus ESL.

\section{ACKNOWLEDGEMENTS}

The authors are especially grateful for the samples received from the Institute of Security Provisional (PAMI), Chemistry Service of the Infantile Hospital, Biochemist Luciana Caeiro from the Children's Hospital, Biochemist Javier Aguilar and the staff from the Blood Bank of the Municipality of Cordoba.

\section{REFERENCES}

1. BERGE, T.O., ed. - International catalogue of arboviruses including certain other viruses of vertebrates. Washingthon, Departament of Health, Education and Welfare, 1975. (DHEW Publication No. (CDC) 75-8301).

2. CAUSEY, O.R. \& THEILER, M. - Virus antibody survey on sera of residents of the Amazon Valley in Brazil. Amer. J. trop. Med. Hyg., 7: 36-41, 1958.

3. EARLY, E.; PERALTA, P.H. \& JOHNSON, K.M. - A plaque neutralization method for arboviruses. Proc. Soc. exp. Biol. (N.Y.), 25: 741-747, 1967.

4. EVANS, A.S.; CASALS, J.; OPTON, E.M. et al. - A nationwide serum survey of Argentinian military recruits, 1965-1966. I. Description of sample and antibody patterns with arboviruses, polioviruses, respiratory viruses, tetanus and treponematosis. Amer. J. Epidem., 93: 111-121, 1971.

5. FRANCIS, B.; GREEN, M. \& PAYNE, C. - The GLIM system. Release 4 manual. Oxford, Clarendon Press, 1993.

6. Mc CULLAGH, P. \& NELDER, J. - Generalized linear models. 2. ed. London, Chapman \& Hall, 1989.

7. METTLER, N.E. \& CASALS, J. - Isolation of St. Louis encephalitis virus from man in Argentina. Acta virol., 15: 148-154, 1971.

8. MITCHELL, C.J.; MONATH, T.P.; SABATTINI, M.S. et al. - Arbovirus investigations in Argentina, 1977-1980. II. Arthropod collections and virus isolations from Argentine mosquitoes. Amer. J. trop. Med. Hyg., 34: 945-955, 1985. 
9. MITCHELL, C.J.; MONATH, T.P.; SABATTINI, M.S. et al. - Arbovirus isolations from mosquitoes collected during and after the 1982-1983 epizootic of western equine encephalitis in Argentina. Amer. J. trop. Med. Hyg., 36: 107-113, 1987.

10. MONATH, T. \& HEINZ, F. - Flavivirus. In: FIELDS, B.N.; KNIPE, D.M.; HOWLEY, P.M., et al. Fields Virology. 3. ed. Philadelphia, Lippincott-Raven, 1996. p. 961984.

11. PINHEIRO, F.P.; SCHATZMAYR, H.G.; TRAVASSOS DA ROSA, A.P.H.; HOMMA, A. \& BENSABATH, G. - Arbovirus antibodies in children of rural Guanabara, Brazil. Intervirology, 5: 93-96, 1975.

12. PINHEIRO, F.P.; LE DUE, J.W.; TRAVASSOS DA ROSA, A.P.H. \& LEITE, O.F. Isolation of St. Louis encephalitis virus from a patient in Belem, Brazil. Amer. J. trop. Med. Hyg., 30: 145-148, 1981.
13. SABATTINI, M.S.; AVILÉS, G. \& MONATH, T.P. - Historical, epidemiological and ecological aspects of arbovirus in Argentina: Flaviviridae, Bunyaviridae and Rhabdoviridae. In: TRAVASSOS DA ROSA, A.P.A.; VASCONCELOS, P.F.C. \& TRAVASSOS DA ROSA, J.F.S., ed. Overview of arbovirology in Brazil and neighboring countries. Belém, Instituto Evandro Chagas, 1998. p. 113-134.

14. SPINSANTI, L.; RÉ, V.; BASUALDO, M.A. et al. - Seroprevalencia de infección por el virus Encefalitis San Luis en la provincia de Formosa. Medicina (B. Aires), 60: 474-476, 2000.

15. TRENT, D.W.; MONATH, T.P.; BOWEN, G.S. et al. - Variation among strains of St. Louis encephalitis virus: basis for a genetic, pathogenetic and epidemiological classification. Ann. N. Y. Acad. Sci., 354: 219-237, 1980.

Received: 14 September 2001

Accepted: 10 January 2002 